\title{
Chapter 1 SDG 1: No Poverty - Impacts of Social Protection, Tenure Security and Building Resilience on Forests
}

Kathleen Lawlor*, Erin Sills*, Stibniati Atmadja, Liwei Lin and Karnjana Songwathana

\section{Key Points}

- The relationship between poverty reduction and forests varies across regions, decades, stage in the forest transition and degree of market access.

- Achieving the specific targets of SDG 1, such as social protection and secure land tenure, can have positive effects on forests, especially if benefits are conditional on forest conservation.

- The overall effect on forests of pursuing SDG 1 depends on which poverty reduction policies are pursued; for instance, allocating forest land to poor farmers has very different implications for land use than targeting payments for ecosystem services to poor farmers.

- Exposure and vulnerability to environmental shocks in coastal areas and near steep slopes can be mitigated by forests - if the poor retain access to forest products and ecosystem services.

\subsection{Introduction}

SDG 1 seeks to 'end poverty in all its forms everywhere'. Poverty is increasingly recognised as a multidimensional concept. For example, the UN Multidimensional Poverty Index (used in the UN Human Development Reports) considers multiple deprivations that people might experience in the domains of health, education and standard of living (UNDP 2018). The World Bank's (2001) 'attacking poverty' framework is another widely used multidimensional approach to poverty (see Lawlor et al. 2013 for an application to forests). Building on the work of Sen (1999), this framework focuses on how opportunities, security and empowerment interact to promote human wellbeing. While quantifying all of these dimensions remains a challenge, the World Bank (2018) reports multidimensional indices of poverty that encompass multiple SDGs through measures of educational achievement (SDG 4),

\footnotetext{
* Lead authors.
} 
access to drinking water and sanitation (SDG 6) and access to electricity (SDG 7), as well as considering whether income is sufficient to satisfy basic needs (SDG 1). Thus, the SDGs taken together embody the multidimensional approach to human development and poverty reduction.

Target 1.1 of SDG 1 focuses squarely on consumption poverty by calling for eradication of extreme poverty as defined by a monetary threshold (Table 1.1). However, SDG 1 also engages with other dimensions of poverty, recognising 'poverty in all its dimensions according to national definitions' (Target 1.2). Targets 1.3-1.5 specify how to reduce poverty: by ensuring that the poor are covered by social protection systems; by securing the rights of the poor to economic resources, access to basic services and property ownership; and by building their resilience to economic, social and environmental shocks.

In this chapter, we focus on the three targets under SDG 1 that specify strategies for reducing poverty, allowing us to draw on the existing evidence base about how those strategies affect forests. Specifically, we examine the potential consequences for forests of (1) implementing social protection systems that cover the poor and vulnerable (Target 1.3), (2) increasing the land tenure

\section{Table 1.1 SDG 1 Targets}

1.1 Eradicate extreme poverty for all people everywhere, currently measured as people living on less than $\$ 1.25$ a day

1.2 Reduce at least by half the proportion of men, women and children of all ages living in poverty in all its dimensions according to national definitions

1.3 Implement nationally appropriate social protection systems and measures for all, including floors, and achieve substantial coverage of the poor and the vulnerable

1.4 Ensure that all men and women, in particular the poor and the vulnerable, have equal rights to economic resources, access to basic services, ownership and control over land and other forms of property, inheritance, natural resources, appropriate new technology and financial services, including microfinance

1.5 Build the resilience of the poor and those in vulnerable situations and reduce their exposure and vulnerability to climate-related extreme events and other economic, social and environmental shocks and disasters

1.A Ensure significant mobilization of resources from a variety of sources, including through enhanced development cooperation

1.B Create sound policy frameworks at the national, regional and international levels, based on pro-poor and gender-sensitive development strategies

Source: Adapted from https://sustainabledevelopment.un.org/sdg1 
security of the poor (Target 1.4) and (3) reducing the vulnerability of the poor and building their resilience to shocks (Target 1.5). Recognising that more than 75 per cent of the global poor live in rural areas (World Bank 2016) and that poverty and forest cover are coincident in many parts of the world (Sunderlin et al. 2008), our analysis of these three targets focuses on the rural poor and their relationships with forests. ${ }^{1}$ These relationships are moderated by market access e.g. through its effect on land rents and therefore incentives for deforestation (Angelsen 2010, Pfaff et al. 2007) - as well as through its effects on employment opportunities, credit availability and insurance against environmental shocks.

We set the stage for our analysis of these relationships by examining the correlation between forests and extreme poverty (defined by a global income/ consumption standard) at the cross-country level (as relevant to Target 1.1) and the role of forests in national poverty reduction strategies (as relevant to Target 1.2). We conclude the chapter by relating our analysis to the means of implementation for SDG 1, suggesting that the implications for forests depend on whether national policymakers recognise the role of forests in rural livelihoods.

\subsection{Relationship between Forests and Poverty}

The relationship between poverty and forests is the subject of a large body of literature. Household-level studies have demonstrated how forests support rural livelihoods - as a source of subsistence, a safety net and a potential pathway out of poverty (Cheng et al. 2017) - through ecosystem products (Angelsen et al. 2014, Shackleton et al. 2011) and services (Daw et al. 2011). In the other direction, poverty or income level is often included as a potential driver of deforestation in models at both the micro- and macro-scale (Atmadja and Sills 2015, Busch and Ferretti-Gallon 2017). Atmadja and Sills (2015) conclude that evidence on the relationship is mixed, with studies of Latin America more likely to find an environmental Kuznet's curve (Choumert et al. 2013) or win-lose relationship (i.e. correlated poverty reduction and deforestation). The environmental Kuznet's curve is one possible explanation for the 'forest transition', or the widely observed empirical regularity that forest cover declines until a turning point or transition, after which gains in forest cover due to natural regeneration and plantations overtake losses due to deforestation (Angelsen and Rudel 2013). The mechanisms underlying this common path vary across regions and reflect the mutual effects forests and economic development have on each other (Rudel et al. 2005). The effect on

\footnotetext{
${ }^{1}$ Due to greater purchasing power, a poor urban family may have a greater impact on forests than a rural family living in extreme poverty. However, given that the goal is to eradicate poverty, we choose to focus on the more numerous rural poor.
} 
forests of external aid to reduce poverty is likely to vary depending on the stage of the forest transition, possibly accelerating forest loss in early stages and encouraging the transition to forest recovery in later stages.

To provide empirical context we plot national poverty rates against forest cover across three decades and four regions. While acknowledging that trends and patterns in poverty vary depending on the dimensions considered and the thresholds applied (World Bank 2018), we consider the percentage of the population living in extreme poverty, as measured by the USD 1.90 per day threshold established by the World Bank in 2015 and consistent with SDG Target 1.1. ${ }^{2}$ As shown in Figure 1.1, in East Asia and Latin America an
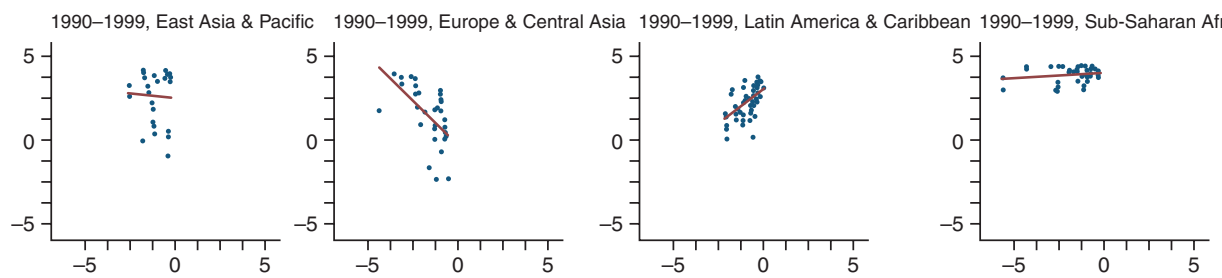

2000-2009, East Asia \& Pacific 2000-2009, Europe \& Central Asia 2000-2009, Latin America \& Caribbean 2000-2009, Sub-Saharan Africa
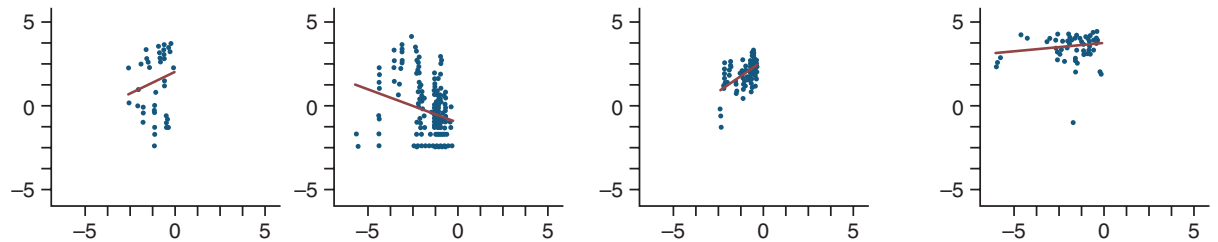

2010-2016, East Asia \& Pacific 2010-2016, Europe \& Central Asia 2010-2016, Latin America \& Caribbean 2010-2016, Sub-Saharan Africa
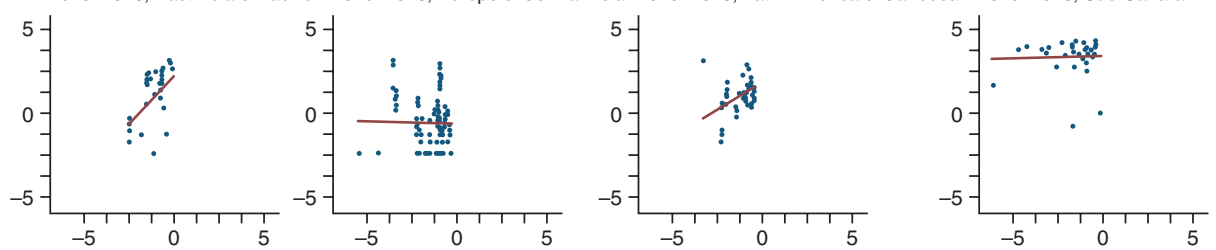

Natural log of \% forest in total land area

- Natural log \% population under $\$ 1.90 /$ day

Fitted values

Graphs by Decades and Region

Figure 1.1 Relationship between forest cover and poverty, by decades and regions. Data source: World Bank. ${ }^{3}$

2 See Ferreira et al. (2015) for an explanation of why, despite using different numbers, the SDG USD 1.25 per day and World Bank USD 1.90 per day poverty thresholds are consistent.

${ }^{3}$ Total land size by country: https://data.worldbank.org/indicator/AG.LND.TOTL.K2 Total population by country and year: https://data.worldbank.org/indicator/SP.POP.TOTL Poverty headcount earning less than USD 1.90/day (percentage of total population) by country and year (not all years are available for each country): https://data.worldbank.org/indicator/SI.POV .DDAY Forest area (sq km): https://data.worldbank.org/indicator/AG.LND.FRST.K2 
inverse relationship between poverty and forests emerges over time: by the most recent decade, lower poverty rates are clearly associated with higher forest cover. In Europe and Central Asia, higher poverty rates are associated with a higher percentage of forest cover in earlier decades, with no apparent relationship in the most recent decade. In Africa, there is no relationship evident in any decade. While these plots only show correlations, they suggest that the effects on forests of pursuing SDG 1 are likely to vary across regions and time, and that there may not be any systematic relationship in the region with the highest levels of extreme poverty (sub-Saharan Africa). It could be that there are nonlinearities (e.g. kinks, reversed relationships) across the income continuum that are poorly characterised by this simple analysis. For example, those living far above the USD 1.90 per day threshold may have a very different relationship with forests than those living far below it.

To provide policy context we consider the role of forests in Poverty Reduction Strategy Papers (PRSPs). The International Monetary Fund (IMF) considers these policy documents to preserve national ownership of poverty reduction strategies and provide flexibility reflecting the particular circumstances of countries supported through their Poverty Reduction and Growth Trust (IMF 2018). PRSPs reveal whether national governments consider forests and poverty reduction to be 'friends' (i.e. synergistic relationship), 'foes' (i.e. competitive relationship) or completely independent of one another (i.e. no relationship). Pursuit of SDG 1 is likely to lead to better outcomes for forests in countries where conservation and sustainable management of forests are considered synergistic with poverty reduction. Of the 12 low-income or low-middle-income countries with the highest forest cover per capita, 9 have PRSPs. Table 1.2 summarises these, noting both specific references to forests and the overall stance towards forests, revealing policy priorities and political realities.

The PRSPs reflect different national positions on the role of forest conservation and sustainable management in poverty reduction, which we categorise as: (1) no role - forest protection is a responsibility unrelated to poverty reduction; (2) implicit - environmental protection (including forest protection) is a cross-cutting theme but few explicit actions related to forests are included; (3) supporting - forest protection and sustainable management is expected to contribute to poverty reduction, e.g. through ecosystem services; and (4) major - better governance of forests could be a key source of economic growth and thus critical for poverty reduction. Many PRSPs suggest that forests play an implicit or supporting role in poverty reduction. In contrast, the PRSPs consistently identify transportation infrastructure and agricultural development as important means of poverty reduction, both of which are tied to deforestation. This reflects conflicting policy priorities in some countries, while in other countries (especially those with relatively abundant forests and 
Table 1.2 Forests in the PRSPs in countries with high forest cover

\begin{tabular}{|c|c|c|c|c|c|}
\hline $\begin{array}{l}\text { Country, Year of } \\
\text { publication }^{a}\end{array}$ & $\begin{array}{l}\text { Forest (ha) } \\
\text { per capita }\end{array}$ & Reference to forests & $\begin{array}{l}\text { Likely } \\
\text { impact on } \\
\text { forest }\end{array}$ & Role of forest & $\begin{array}{l}\text { Poverty indicator } \\
\text { used }\end{array}$ \\
\hline $\begin{array}{l}\text { Republic of } \\
\text { Bolivia (2001) }\end{array}$ & 5.3 & $\begin{array}{l}\text { Increase rural employment through } \\
\text { better roads, irrigation and electrification } \\
\text { infrastructures, and access to land for } \\
\text { agriculture and settlement; increase export } \\
\text { competitiveness of agricultural products; } \\
\text { increase non-agricultural income, such } \\
\text { as rural tourism; actions to reduce levels } \\
\text { of risk and vulnerability to water scarcity } \\
\text { and natural disasters include reforestation } \\
\text { and environmental conservation through } \\
\text { integrated, sustainable natural resource } \\
\text { management. }\end{array}$ & Negative & $\begin{array}{l}\text { Implicit - Not a } \\
\text { major economic } \\
\text { sector; mainly } \\
\text { to ensure rural } \\
\text { resilience }\end{array}$ & $\begin{array}{l}\text { Income to } \\
\text { purchase a basket } \\
\text { of goods and } \\
\text { services }\end{array}$ \\
\hline $\begin{array}{l}\text { Rep. of Congo } \\
(2012)\end{array}$ & 5.0 & $\begin{array}{l}\text { Improve forestry and wood industry through } \\
\text { specialised schools and industrialisation, } \\
\text { improved forest management, and improved } \\
\text { utilisation of non-wood forest products; forest } \\
\text { conservation through participatory approaches } \\
\text { and strategies such as REDD+, PES and forest } \\
\text { certification. }\end{array}$ & Positive & $\begin{array}{l}\text { Major - Forestry a } \\
\text { source of national } \\
\text { wealth ( } 5.6 \% \\
\text { of GDP, } 10 \% \text { of } \\
\text { foreign trade, } \\
16000 \text { jobs) }\end{array}$ & $\begin{array}{l}\text { Multidimensional } \\
\text { (employment, } \\
\text { access to } \\
\text { services, quality } \\
\text { of governance, } \\
\text { income) }\end{array}$ \\
\hline
\end{tabular}




\begin{tabular}{|c|c|c|c|c|c|}
\hline $\begin{array}{l}\text { Mongolia } \\
\text { (2003) }\end{array}$ & 4.6 & $\begin{array}{l}\text { Forests need to be protected and expanded, } \\
\text { mainly to provide ecosystem services to } \\
\text { support other sectors; notably, livestock } \\
\text { forests are acknowledged for their potential to } \\
\text { generate jobs for the poor, e.g. through tree } \\
\text { planting and forest utilisation. }\end{array}$ & No impact & $\begin{array}{l}\text { Implicit - Mainly } \\
\text { to support } \\
\text { livestock, avoid } \\
\text { desertification and } \\
\text { provide informal } \\
\text { jobs }\end{array}$ & Income \\
\hline $\begin{array}{l}\text { Royal } \\
\text { Government of } \\
\text { Bhutan (2004) }\end{array}$ & 3.6 & $\begin{array}{l}\text { The } 2020 \text { target includes maintaining } 60 \% \\
\text { of Bhutan's land area under forest coverage } \\
\text { in perpetuity (from } 72 \% \text { forest cover in } \\
2004 \text { ), increase access to roads, increase } \\
\text { income and employment; 'preserving and } \\
\text { promoting cultural heritage and environment } \\
\text { conservation' is one of the plan's } 5 \text { main } \\
\text { objectives. }\end{array}$ & Negative & $\begin{array}{l}\text { Supporting - } \\
\text { Strong baseline } \\
\text { environmental } \\
\text { policies and } \\
\text { environmental } \\
\text { conservation is } 1 \text { of } \\
5 \text { pillars of long- } \\
\text { term economic } \\
\text { development }\end{array}$ & $\begin{array}{l}\text { Household } \\
\text { expenditure }\end{array}$ \\
\hline $\begin{array}{l}\text { Republic of } \\
\text { Zambia (2006) }\end{array}$ & 3.3 & $\begin{array}{l}\text { The overall strategy of broad-based wealth and } \\
\text { job creation through economic infrastructure } \\
\text { and human development focuses on rural } \\
\text { development and agriculture (irrigation, food } \\
\text { security, roads, livestock, microfinance); forests } \\
\text { are a part of the natural resources sectoral plan } \\
\text { as the main provider of household energy, } \\
\text { with untapped potential for generating income } \\
\text { from wood industries and tourism. }\end{array}$ & Negative & $\begin{array}{l}\text { Implicit - Forests } \\
\text { contribute } 3.7 \% \text { of } \\
\text { GDP via charcoal } \\
\text { and firewood } \\
\text { production }\end{array}$ & $\begin{array}{l}\text { Income level; } \\
\text { forest loss/ } \\
\text { degradation an } \\
\text { indicator and } \\
\text { result of poverty }\end{array}$ \\
\hline
\end{tabular}


Table 1.2 (cont.)

\begin{tabular}{|c|c|c|c|c|c|}
\hline $\begin{array}{l}\text { Country, Year of } \\
\text { publication }^{\mathrm{a}}\end{array}$ & $\begin{array}{l}\text { Forest (ha) } \\
\text { per capita }\end{array}$ & Reference to forests & $\begin{array}{l}\text { Likely } \\
\text { impact on } \\
\text { forest }\end{array}$ & Role of forest & $\begin{array}{l}\text { Poverty indicator } \\
\text { used }\end{array}$ \\
\hline Lao PDR (2006) & 2.8 & $\begin{array}{l}\text { Effective poverty reduction is achieved } \\
\text { through increased agricultural productivity } \\
\text { and better access to markets via better } \\
\text { roads.; sustainable and participatory forest } \\
\text { management mentioned as a subcomponent } \\
\text { in } 1 \text { of } 5 \text { strategies for reducing rural poverty; } \\
\text { poverty reduction can reduce environmental } \\
\text { degradation, and economic growth can } \\
\text { encourage environmental conservation if } \\
\text { accompanied by education and training and } \\
\text { development of scientific and technological } \\
\text { capacities. }\end{array}$ & Negative & $\begin{array}{l}\text { No role - } \\
\text { Co-location: most } \\
\text { poverty found in } \\
\text { remote highlands, } \\
\text { where forests are } \\
\text { located }\end{array}$ & $\begin{array}{l}\text { Includes lack of } \\
\text { agricultural land }\end{array}$ \\
\hline $\begin{array}{l}\text { Dem. Rep. of } \\
\text { Congo (2006) }\end{array}$ & 2.2 & $\begin{array}{l}\text { As } 1 \text { of } 6 \text { sectors with growth potential, } \\
\text { forestry is targeted with actions to improve } \\
\text { forest management and institutions; } 1 \text { pillar } \\
\text { of poverty reduction is improved governance, } \\
\text { notably in forestry and mining sectors. }\end{array}$ & Positive & $\begin{array}{l}\text { Major - Better } \\
\text { governance } \\
\text { needed to tap into } \\
\text { this income }\end{array}$ & $\begin{array}{l}\text { Peace, access to } \\
\text { public services } \\
\text { and productive } \\
\text { capital, } \\
\text { governance and } \\
\text { meeting basic } \\
\text { needs }\end{array}$ \\
\hline
\end{tabular}




\begin{tabular}{|c|c|c|c|c|c|}
\hline $\begin{array}{l}\text { Rep. of Guinea- } \\
\text { Bissau (2011) }\end{array}$ & 1.3 & $\begin{array}{l}\text { Environmental management and protection } \\
\text { is a subcomponent of promoting inclusive, } \\
\text { sustainable economic development, which is } \\
\text { the last of } 6 \text { core areas in poverty reduction; } \\
\text { the focus is on building capacity to address } \\
\text { natural disasters including forest degradation; } \\
\text { strategy for targeting the very poor focuses on } \\
\text { revitalising agriculture, notably cashew and } \\
\text { rice production. }\end{array}$ & Negative & $\begin{array}{l}\text { Supporting - Small } \\
\text { part of } 1 \text { of } 4 \text { core } \\
\text { areas for poverty } \\
\text { reduction related } \\
\text { to sustainable } \\
\text { economic } \\
\text { development }\end{array}$ & $\begin{array}{l}\text { Monetary and } \\
\text { non-monetary } \\
\text { (housing, } \\
\text { sanitation, safe } \\
\text { drinking water, } \\
\text { consumer } \\
\text { durables) }\end{array}$ \\
\hline $\begin{array}{l}\text { United Rep. of } \\
\text { Tanzania (2010) }\end{array}$ & 1.0 & $\begin{array}{l}\text { Alleviate income poverty by focusing on } \\
\text { identified growth areas in agriculture, tourism, } \\
\text { manufacturing and mining, and cross-sectoral } \\
\text { drivers (e.g. roads, energy, water); forestry and } \\
\text { forest products are one of } 7 \text { agricultural sub- } \\
\text { sectors targeted for growth by 2015, as part } \\
\text { of reducing income poverty; forest is a factor } \\
\text { of production that needs to be used more } \\
\text { efficiently for productivity gains and value } \\
\text { addition. }\end{array}$ & Negative & $\begin{array}{l}\text { Supporting - via } \\
\text { tourism, rural job } \\
\text { creation }\end{array}$ & $\begin{array}{l}\text { Income, well- } \\
\text { being, and good } \\
\text { governance }\end{array}$ \\
\hline
\end{tabular}


relatively low income) it reflects the view that forest resources are a means of economic development (Maini 2003). In sum, while the PRSPs suggest a wide range of approaches to forest policy, their almost universal call to alleviate rural poverty through agricultural and infrastructural development is likely to result in forest loss.

\subsection{Social Protection}

Target 1.3 calls for implementing nationally appropriate social protection systems and measures for all, including floors, and achieving substantial coverage of the poor and the vulnerable. Tirivayi et al. (2017) point out that forest-dependent peoples are typically poor and vulnerable, and therefore in particular need of social protection. Social protection systems, including programmes such as unemployment insurance and pensions for the elderly, are designed to help people cope with shocks and meet their basic needs. Over the past 20 years, cash transfer programmes have become a prominent component of social protection systems throughout the developing world (Handa et al. 2017, Hulme et al. 2012).

In addition to protecting recipients' human capital, cash transfer programmes can also affect households' economic production. The intent of most cash transfer programmes is to break the intergenerational transmission of poverty to children and build their human capital by increasing their consumption of food, health services and education (Baird et al. 2014, Bastagli et al. 2016, Manley et al. 2013). But cash transfers can also affect the economic production of households, especially family farmers who are otherwise cash constrained. These changes in households' production could impact forest resources both positively and negatively. For example, infusions of cash could increase pressure on forests if they enable households to expand their agricultural operations. Or, transfers could decrease pressure on local ecosystems if they enable migration to cities or the establishment of non-farm businesses.

There are multiple other pathways through which cash transfers could affect forests. A regular cash flow could make households less vulnerable to income shocks and thus less likely to rely on forests as 'natural insurance' (Pattanayak and Sills 2001) through harvesting and selling forest products. Cash transfers can enable increased consumption, with significant effects on deforestation locally or through markets for products that drive deforestation, such as beef, milk, soy and palm oil. Tracking the associated supply responses across space and time is challenging, making it difficult to quantify the full causal impacts of social protection systems on forests. 
Many studies examine the effects of cash transfers on agricultural productivity. They typically find that in addition to building children's human capital, cash transfers help households increase their agricultural output (Tirivayi et al. 2016). This empirical regularity is likely associated with the other consistent finding that transfers increase purchases of agricultural inputs, such as chemical fertiliser. This could mean transfers are promoting agricultural intensification (increases in agricultural output without corresponding increases in hectares farmed), although increases in the area farmed (i.e. extensive agriculture) are also possible. Among these studies, there are a few that directly consider impacts on land use, including forests.

Our search of the literature uncovered ten studies of how cash transfers to the rural poor affect natural resources, including one study of remittances rather than government transfers (López-Feldman and Chávez 2017). Table 1.3 summarises the nine studies that estimate impacts on land use (the tenth study - Gilliland et al. 2018 - focuses on fisheries). All of the study sites are in the early stage of the forest transition, i.e. forest loss is ongoing. The recipients of the cash transfers generally have limited market access. Two of the studies (Alix-Garcia et al. 2013, Ferraro and Simorangkir 2018) combine household survey data with geospatial data to identify impacts on forests; the remaining seven report impacts on land used for farming. Two of the studies (Lawlor 2015, López-Feldman and Chávez 2017,) also examine impacts on forest product harvesting. Finally, two of the studies (Alix-Garcia et al. 2013, Lawlor 2015) explore how variations in market access affect transfers' impacts on natural resources. Overall, this literature finds that both conditional and unconditional cash transfer programmes have significant impacts on consumption and production in the short run (e.g. after only two years of payments).

Specifically, there is evidence that cash transfers might be encouraging land intensification in Lesotho (Daidone et al. 2014) and among farmers with larger landholdings in Mexico (Gertler et al. 2012, Todd et al. 2010). Transfers are promoting agricultural expansion among smallholders and those receiving agricultural subsidies in Mexico (Todd et al. 2010), Malawi (Asfaw et al. 2016b) and Zambia (Lawlor 2015). Cash is enabling the previously landless to farm in Mexico (Gertler et al. 2012, Todd et al. 2010) and increasing the number of farmers in Ethiopia (Asfaw et al. 2016a) and in Zambia among households living more than $10 \mathrm{~km}$ from markets (Lawlor 2015). In Ethiopia, transfers are reducing the likelihood of leaving land fallow (Asfaw et al. 2016a). The only evidence that cash transfers can decrease the likelihood of participating in agriculture comes from the López-Feldman and Chávez (2017) study of remittances in Mexico. However, their sample 
Table 1.3 Studies evaluating the effect of cash transfers on land use

\begin{tabular}{|c|c|c|c|c|c|}
\hline \multirow{2}{*}{$\begin{array}{l}\text { Authors } \\
\text { (year) }\end{array}$} & \multirow{2}{*}{$\begin{array}{l}\text { Country, } \\
\text { programme }\end{array}$} & \multirow{2}{*}{$\begin{array}{l}\text { Type of income } \\
\text { support* }\end{array}$} & \multirow[t]{2}{*}{ Study design } & \multicolumn{2}{|c|}{ Impacts of cash transfers on ... } \\
\hline & & & & Land use & $\begin{array}{l}\text { Non-farm business and wage } \\
\text { labour }\end{array}$ \\
\hline $\begin{array}{l}\text { Todd et al. } \\
\text { (2010) }\end{array}$ & $\begin{array}{l}\text { Mexico, } \\
\text { Oportunidades }\end{array}$ & $\begin{array}{l}\text { CCT for extremely } \\
\text { poor households } \\
\text { with children }\end{array}$ & $\begin{array}{l}\text { Treatment- } \\
\text { comparison } \\
\text { with } \\
\text { randomised } \\
\text { data and } \\
\text { matching } \\
\text { weights }\end{array}$ & $\begin{array}{l}\text { - Increases likelihood of farming } \\
\text { land among previously landless } \\
\text { - Increases per capita area farmed } \\
\text { by smallholders; no change for } \\
\text { large landholders } \\
\text { - Increases in area farmed, largest } \\
\text { for those receiving agricultural } \\
\text { subsidies }\end{array}$ & Not reported \\
\hline $\begin{array}{l}\text { Gertler } \\
\text { et al. } \\
(2012)\end{array}$ & $\begin{array}{l}\text { Mexico, } \\
\text { Oportunidades }\end{array}$ & $\begin{array}{l}\text { CCT for extremely } \\
\text { poor households } \\
\text { with children }\end{array}$ & $\begin{array}{l}\text { Randomised } \\
\text { treatment - } \\
\text { control }\end{array}$ & $\begin{array}{l}\text { - Increases likelihood of farming } \\
\text { land among previously landless } \\
\text { - No impact on land area used } \\
\text { among landed farmers }\end{array}$ & $\begin{array}{l}\text { - Increases likelihood of } \\
\text { owning non-farm business }\end{array}$ \\
\hline $\begin{array}{l}\text { Alix-Garcia } \\
\text { et al. } \\
(2013)\end{array}$ & $\begin{array}{l}\text { Mexico, } \\
\text { Oportunidades }\end{array}$ & $\begin{array}{l}\text { CCT for extremely } \\
\text { poor households } \\
\text { with children }\end{array}$ & $\begin{array}{l}\text { Instrumental } \\
\text { variable }\end{array}$ & $\begin{array}{l}\text { - Increases deforestation due to } \\
\text { increased consumption of beef } \\
\text { and milk } \\
\text { - Impacts appear larger in } \\
\text { isolated communities }\end{array}$ & Not reported \\
\hline $\begin{array}{l}\text { Daidone } \\
\text { et al. } \\
(2014)\end{array}$ & $\begin{array}{l}\text { Lesotho, } \\
\text { Child Grant } \\
\text { Program }\end{array}$ & $\begin{array}{l}\text { UCT for poor } \\
\text { households with } \\
\text { children }\end{array}$ & $\begin{array}{l}\text { Randomised } \\
\text { treatment - } \\
\text { control }\end{array}$ & $\begin{array}{l}\text { - No impact on the probability of } \\
\text { growing crops or area farmed }\end{array}$ & $\begin{array}{l}\text { - Reduces non-farm } \\
\text { businesses for labour- } \\
\text { constrained households } \\
\text { - Reduces participation in } \\
\text { wage labour }\end{array}$ \\
\hline
\end{tabular}




\begin{tabular}{|c|c|c|c|c|c|}
\hline $\begin{array}{l}\text { Asfaw et al. } \\
\text { (2016a) }\end{array}$ & $\begin{array}{l}\text { Ethiopia, } \\
\text { Tigray Social Cash } \\
\text { Transfer Pilot } \\
\text { Programme }\end{array}$ & $\begin{array}{l}\text { UCT for extremely } \\
\text { poor, labour- } \\
\text { constrained } \\
\text { households }\end{array}$ & $\begin{array}{l}\text { Matched } \\
\text { treatment - } \\
\text { comparison }\end{array}$ & $\begin{array}{l}\text { - Increases probability of growing } \\
\text { crops } \\
\text { - Decreases likelihood of leaving } \\
\text { land fallow }\end{array}$ & $\begin{array}{l}\text { - Reduces non-farm } \\
\text { businesses for female- } \\
\text { headed households } \\
\text { - Reduces participation in } \\
\text { wage labour }\end{array}$ \\
\hline $\begin{array}{l}\text { Asfaw et al. } \\
(2016 b)\end{array}$ & $\begin{array}{l}\text { Malawi, } \\
\text { Social Cash } \\
\text { Transfer Program }\end{array}$ & $\begin{array}{l}\text { UCT for extremely } \\
\text { poor, labour- } \\
\text { constrained } \\
\text { households }\end{array}$ & $\begin{array}{l}\text { Randomised } \\
\text { treatment - } \\
\text { control }\end{array}$ & $\begin{array}{l}\text { - Increases area farmed } \\
\text { - Increases adoption of } \\
\text { sustainable farming practices }\end{array}$ & $\begin{array}{l}\text { - Reduces non-farm } \\
\text { businesses for labour- } \\
\text { constrained and female- } \\
\text { headed households } \\
\text { - Reduces charcoal/ } \\
\text { firewood businesses and } \\
\text { increases petty trade } \\
\text { enterprises } \\
\text { - Increases number of days } \\
\text { adult males spend earning } \\
\text { wage income }\end{array}$ \\
\hline $\begin{array}{l}\text { López- } \\
\text { Feldman } \\
\text { and Chávez } \\
\text { (2017) }\end{array}$ & Mexico & Remittances & $\begin{array}{l}\text { Instrumental } \\
\text { variable }\end{array}$ & $\begin{array}{l}\text { - Decreases likelihood of } \\
\text { participating in agriculture or } \\
\text { natural resource extraction } \\
\text { as well as reliance on } \\
\text { environmental income }\end{array}$ & $\begin{array}{l}\text { - Increases likelihood of } \\
\text { earning wage income }\end{array}$ \\
\hline
\end{tabular}


Table 1.3 (cont.)

\begin{tabular}{|c|c|c|c|c|c|}
\hline \multirow{2}{*}{$\begin{array}{l}\text { Authors } \\
\text { (year) }\end{array}$} & \multirow{2}{*}{$\begin{array}{l}\text { Country, } \\
\text { programme }\end{array}$} & \multirow{2}{*}{$\begin{array}{l}\text { Type of income } \\
\text { support* }^{*}\end{array}$} & \multirow[t]{2}{*}{ Study design } & \multicolumn{2}{|c|}{ Impacts of cash transfers on ... } \\
\hline & & & & Land use & $\begin{array}{l}\text { Non-farm business and wage } \\
\text { labour }\end{array}$ \\
\hline $\begin{array}{l}\text { Ferraro and } \\
\text { Simorangkir } \\
(2018)\end{array}$ & $\begin{array}{l}\text { Indonesia, } \\
\text { Program Keluarga } \\
\text { Harapan }\end{array}$ & $\begin{array}{l}\text { CCT for extremely } \\
\text { poor households } \\
\text { with children }\end{array}$ & $\begin{array}{l}\text { Matched } \\
\text { treatment- } \\
\text { comparison }\end{array}$ & - Reduces village forest loss & Not reported \\
\hline $\begin{array}{l}\text { Lawlor } \\
(2015)\end{array}$ & $\begin{array}{l}\text { Zambia, } \\
\text { Child Grant } \\
\text { Programme }\end{array}$ & $\begin{array}{l}\text { UCT for } \\
\text { households with a } \\
\text { child under age } 5\end{array}$ & $\begin{array}{l}\text { Randomised } \\
\text { treatment - } \\
\text { control }\end{array}$ & $\begin{array}{l}\text { - No impacts on fuelwood or } \\
\text { bushmeat } \\
\text { Close to markets }(<10 \mathrm{~km}) \\
\text { - increases use of charcoal } \\
- \text { no impact on decision to farm } \\
\text { - increases area farmed } \\
\text { Far from markets (> } 10 \mathrm{~km}) \\
\text { - no impact on charcoal use } \\
\text { - increases likelihood of farming } \\
\text { - increases area farmed }\end{array}$ & $\begin{array}{l}\text { - Increases likelihood of } \\
\text { owning non-farm business }\end{array}$ \\
\hline
\end{tabular}


excludes the country's smallest villages, with perhaps the most limited market access. Across the studies there is no evidence that cash transfers promote afforestation/reforestation.

In addition to agricultural impacts, two studies estimate impacts on households' natural resource use. In Mexico, remittances decreased harvesting of natural resources (firewood, timber and wild fruits, plants and meat) as well as reliance on environmental income (López-Feldman and Chávez 2017), supporting the hypothesis that transfers can replace natural insurance. However, in Zambia, cash transfers had no impact on consumption of bushmeat or fuelwood, and for households living within $10 \mathrm{~km}$ of markets, transfers increased the likelihood of using charcoal by 10 percentage points (Lawlor 2015). This is especially notable because charcoal is the principal driver of forest loss in Zambia (Day et al. 2014) and many other African countries, highlighting the importance of coupling poverty reduction programmes with clean energy initiatives (see Chapter 7).

Some of the studies reviewed also estimate impacts on livelihood strategies beyond farming and natural resource use. For example, in Mexico transfers increased the number of households owning small businesses by 67 per cent (Gertler et al. 2012), and remittances increased the likelihood of earning wage income by 14 percentage points (López-Feldman and Chávez 2017). In Zambia, transfers promoted diversification into non-farm businesses, with much larger impacts on those living close to markets (increased likelihood by 23 percentage points) than those living far from markets (increased likelihood by 11 percentage points) (Lawlor 2015). The magnitude of these impacts on non-farm businesses is quite large, especially considering these impacts are estimated after only two years of cash transfers. Taken together, these results provide evidence that cash transfers can help households diversify livelihood strategies, and may decrease pressure on forests over the long run by decreasing reliance on agriculture for income.

The two studies that harness geospatial data to identify the impacts of cash transfers on forests are most relevant to the question of how reducing poverty will impact forests because they capture not only how beneficiary households respond, but also spillovers to other households. Cash transfers could have significant multiplier effects, raising non-beneficiaries' consumption and production while avoiding inflation (Handa et al. 2017, 2018). This could have implications for land use, for instance, if beneficiaries' increased demand for food is met by increased food production by their neighbours or neighbouring communities. However, the two studies provide contradictory results. Alix-Garcia et al. (2013) find that transfers increased deforestation in Mexico, whereas Ferraro and Simorangkir (2018) find that cash transfers decreased deforestation in Indonesia. Both studies examine impacts after five 
years of payments. In Mexico, cash transfers increased deforestation rates by 15-33 per cent. The authors investigate how impacts vary according to market access and observe the largest impacts in isolated communities, which they conclude is because better market access diffuses the supply response across other communities. In Indonesia, on the other hand, transfers reduced village forest loss by 20 per cent ( $3.63 \mathrm{ha}$ ). The authors find some heterogeneity of impacts across forest governance institutions, with the largest reductions in forest loss in community forests, followed by concessions and protected areas. This raises the question of whether the cash transfers influence collective action, as well as household livelihood strategies. Further research is needed to understand the causal mechanisms.

Taken together, what can we say about the potential impact on forests of expanding the coverage of social protection systems? Clearly, the impacts of cash transfers vary by region due to differences in access to markets for land, labour, inputs and outputs, as well as differences in forest clearance costs and land tenure. The Indonesia study is the only one that finds clear positive impacts on forests. The remaining studies suggest that in the short run, rural households invest part of the transfers in their farms and that this results in the expansion of farmed area. Furthermore, households increase their food consumption, which elicits a supply response that increases pressure on forests. In the long run, some households living close to markets may be able to shift out of agriculture to non-farm businesses or wage labour, decreasing pressure on forests (cf. Sierra and Russman 2006). This could be encouraged by making cash transfers conditional on forest conservation, as in payments for ecosystem services (PES) (Alix-Garcia and Wolff 2014, Rodríguez et al. 2011). PES are often presented as a means to reduce both rural poverty and ecosystem degradation, although the targeting rules that maximise poverty reduction are likely to differ from the rules that maximise conservation benefits (James and Sills 2018). Both experience and field experiments have demonstrated the importance of local institutions in moderating the effects of PES, including effects on poverty (Sills and Jones 2018). The moderating effect of community tenure in the Indonesia case (Ferraro and Simorangkir 2018) suggests this may also be true of cash transfers.

\subsection{Land Tenure}

Target 1.4 calls for ensuring equal rights to economic resources, as well as access to basic services, ownership and control over land and other forms of property, inheritance, natural resources, appropriate new technology and financial services. Access depends fundamentally on transportation infrastructure (SDG 9) and basic services including housing (SDG 11), water (SDG 
6) and energy (SDG 7), all of which can generate demand for ecosystem products and/or services, with implications for forests. In this section we focus on ownership and control over land, in particular on the security of private and communal land tenure.

Land tenure encompasses the institutions and policies that determine how land and its resources are accessed, who can hold and use these resources, for how long and under what conditions (Robinson et al. 2014). Tenure regimes can be characterised both by who holds rights (an individual, a community, a private entity, the state or, in the case of open access, no one) and by the security of those rights (defined by degree of protection against eviction and ability to exclude others). Elbow (2014) notes that tenure security can be achieved through public recognition of customary or Indigenous rights, certificates that secure the rights to use or manage resources, or titling of community-managed land or individual property rights. This is reflected in Indicator 1.4.2, which measures both the fraction of the population with legally recognised documentation of land tenure and the fraction of the population who perceive their rights to land as secure. Land tenure security is the perception that rights will be upheld by society (Sjaastad and Bromley 2000) or the certainty 'that a person's rights to land will be recognised by others and protected in cases of specific challenges' (Land Portal 2018). Securing land tenure has long been recognised as a tool for reducing poverty and enhancing economic development since it can both encourage investment and facilitate access to credit.

The security of land tenure affects forests through several channels. First, the need to secure tenure by demonstrating investment in the land may encourage deforestation in some contexts (Alston et al. 2000) and tree planting in others (Barbier and Tesfaw 2013). In many contexts, insecure tenure creates disincentives to invest in reforestation or forest management since land users have no assurance of reaping future benefits (Chazdon et al. 2016). Additionally, when forest users perceive their rights to the resource as timelimited or insecure, they are incentivised to harvest as much of the resource as fast as possible. Numerous studies have found that insecure land tenure promotes faster timber harvesting (Dorner and Thiesenhusen 1992, Puppim de Oliveira 2008, White and Martin 2002). Where the agents of deforestation are external to the customary occupants of the land, tenure insecurity for those occupants means that they do not have clear rights or incentives to defend forests from the external agents. Finally, access to technical assistance and direct conditional incentives to conserve forest (such as REDD+) may require secure tenure (Larson et al. 2013). On the other hand, increasing land tenure security can increase deforestation if it encourages investment in profitable agricultural activities that replace forest, such as plantation crops, 
or sale of land to agents that plan to clear the forest (Liscow 2013). In sum, the literature reports cases of tenure security both reducing and increasing deforestation, with differences related to livelihood strategies, socio-cultural institutions, tenure type, level of inequality (in communal tenure systems) and numerous other factors.

In a recent systematic review, Robinson et al. (2014) identify 36 publications that report 118 relationships between specific forms and security of tenure and (sub)tropical deforestation. All major regions of the tropics are represented in their sample. They categorise studies based on whether tenure security has a causal relationship with positive forest outcomes (defined as slowing deforestation or maintaining/regenerating forests) or negative forest outcomes (defined as accelerating deforestation). They find that communal (but not private or customary/traditional) tenure increases the likelihood of positive forest outcomes. Tenure security is consistently associated with positive forest outcomes across all types of tenure. This contrasts with the findings of a meta-analysis of spatially explicit econometric studies of deforestation by Busch and Ferretti-Gallon (2017). Based on 27 studies that estimate the effect of tenure security (defined as land ownership, legal title or duration of occupancy), they conclude that there is no systematic relationship between tenure security and deforestation.

To update the findings of Robinson et al. (2014) and Busch and FerrettiGallon (2017), we searched for recent studies (published in 2014 or later) of how tenure security affects forests, focusing on private and communal tenure. Like Robinson et al. (2014), we only include studies that give some indication of the degree to which tenure rights are secure. Following Robinson et al. (2014), we define forest outcomes as either positive or negative and only include studies that give some indication of the degree to which tenure rights are secure. The results of seven recent studies are summarised in Table 1.4. All of these studies estimate the effects of circumstances or interventions that increase tenure security.

L'Roe et al. (2016) find that formalising individual land claims in the eastern Brazilian Amazon by mapping and recording them in a state-run registry decreases deforestation on medium-sized properties (100-300 ha). Registration of land claims, however, has no impact on deforestation of larger properties. Holland et al. (2017) find the titling of private lands around a reserve only reduces deforestation when accompanied by 'forest friendly' restrictions.

In Uganda, Call et al. (2017) find that households are more likely to engage in tree-planting if they have secure tenure, are educated and live in isolated communities. In China, Lin et al. (2018) find that these types of investments are more likely when households can obtain logging permits but are not affected by tenure security. 


\begin{tabular}{|c|c|c|c|c|c|c|}
\hline & \multicolumn{3}{|c|}{ Common-Property Regime } & \multicolumn{3}{|c|}{ Individual Property } \\
\hline & $\begin{array}{l}\text { Positive } \\
\text { Outcome } \\
\text { for } \\
\text { Forests }\end{array}$ & $\begin{array}{l}\text { Negative } \\
\text { Outcome } \\
\text { for } \\
\text { Forests }\end{array}$ & $\begin{array}{l}\text { No } \\
\text { Impact }\end{array}$ & $\begin{array}{l}\text { Positive } \\
\text { Outcome } \\
\text { for } \\
\text { Forests }\end{array}$ & $\begin{array}{l}\text { Negative } \\
\text { Outcome } \\
\text { for } \\
\text { Forests }\end{array}$ & $\begin{array}{l}\text { No } \\
\text { Impact }\end{array}$ \\
\hline Brazil & & & $\begin{array}{l}\text { BenYishay } \\
\text { et al. } \\
(2017)\end{array}$ & $\begin{array}{l}\text { L'Roe } \\
\text { et al. } \\
\text { (2016) }\end{array}$ & & \\
\hline China & & & & & & $\begin{array}{l}\text { Lin } \\
\text { et al. } \\
(2018)\end{array}$ \\
\hline Ecuador & & & $\begin{array}{l}\text { Buntaine } \\
\text { et al. } \\
(2015)\end{array}$ & $\begin{array}{l}\text { Holland } \\
\text { et al. } \\
(2017)^{*}\end{array}$ & & \\
\hline Peru & $\begin{array}{l}\text { Blackman } \\
\text { et al. } \\
(2017)\end{array}$ & & & & & \\
\hline Uganda & & & & $\begin{array}{l}\text { Call et al. } \\
(2017)\end{array}$ & & \\
\hline
\end{tabular}

Both Buntaine et al. (2015) and BenYishay et al. (2017) find that formalising Indigenous communities' land rights in Ecuador and Brazil, respectively, has no impact on rates of forest loss. In contrast, Blackman et al. (2017) find that titling Indigenous communities' land in Peru dramatically reduced deforestation in just three years. In order to obtain titles, the Peruvian communities had to submit sustainable management plans, which Robinson et al. (2017) argue may be necessary for tenure security to have a positive effect on forests. Blackman and Veit (2018) also find that allocation of tenure rights and management by Indigenous communities reduces deforestation in Bolivia, Brazil and Colombia (but not Ecuador).

In sum, the effect of increasing land tenure security (the perception that rights to land are recognised and will be upheld) on forests is context dependent. The existing evidence base suggests that increasing tenure security rarely leads to forest loss. However, the long-term effects are relatively understudied 
and hence unknown. As with direct cash transfers, there are suggestions that increasing tenure security is most likely to favour forests when accompanied by incentives or conditions that explicitly require forest conservation and sustainable management (Holland et al. 2017, Robinson et al. 2017).

\subsection{Ecosystem-Based Adaptation to Climate Change}

Target 1.5 is 'to build the resilience of the poor and those in vulnerable situations and reduce their exposure and vulnerability to climate-related extreme events and other economic, social and environmental shocks and disasters'. Forests have long been recognised as a safety net or form of natural insurance, providing both cash income and subsistence goods to poor rural households living on the forest margin, thus reducing their vulnerability and increasing their adaptive capacity and livelihood resilience (Agrawal et al. 2013, Byron and Arnold 1999, Pattanayak and Sills 2001). Poor and vulnerable populations tend to concentrate in remote and environmentally fragile areas (Sunderlin et al. 2008, Watmough et al. 2016), and they rely disproportionately on natural resources and ecosystem services to support their livelihoods, for both subsistence and income generation (Barbier 2010, Barrett 2005). This implies they are both more exposed (more often affected) and more vulnerable (lose more when affected relative to their income or wealth) to environmental shocks (Hallegatte et al. 2016). It also implies the effects of environmental shocks are likely to be channelled through ecosystems and moderated by the health of those ecosystems. Thus, managing for improved ecosystem health may be an effective way to reduce the exposure and vulnerability of poor populations to shocks and disasters.

There is increasing scientific and policy consensus that natural ecosystems can contribute to climate change adaptation by reducing exposure to shocks (Doswald et al. 2014, Munang et al. 2013). The role of forests in mitigating climate change itself through REDD+ is discussed in Chapter 13. Forests are often credited with reducing the sensitivity of ecosystems to extreme rainfall events, thus buffering communities from floods (Chapter 6), and mangrove forests can reduce damage from storm surges in coastal areas (Das and Vincent 2009, Chapter 14). Thus, measures to reduce exposure and vulnerability could include reforestation of slopes to prevent landslides and restoration of mangrove shelterbelts to protect coastal settlements against storms (Pramova et al. 2012). These are examples of ecosystem-based adaptation, or the conservation or restoration of natural ecosystems to reduce the vulnerability of people facing climate change threats (Vignola et al. 2009). This may be accomplished through public works programmes that jointly provide social protection and expanded forest cover (Tirivayi 2017). Ecosystem-based 
adaptation has been adopted in some National Adaptation Programmes of Action, as reflected in calls for afforestation and reforestation in Burkina Faso and Mali (to forestall desertification), Bangladesh (to stabilise the coast) and Haiti (to protect watersheds) (Locatelli et al. 2008). Thus, efforts to meet Target 1.5 could result in an expansion of forest area.

\subsubsection{Sloping Land Conservation Program}

The Sloping Land Conservation Program (SLCP) in China is another example of a national forest policy implemented to reduce exposure and vulnerability to environmental shocks. The SLCP is one of several programmes that China launched in response to a perceived 'national land-system sustainability emergency' in the late 1990s (Bryan et al. 2018). With rapid economic growth since the 1980s, China has experienced deforestation and land degradation (Liu and Diamond 2005). Deforestation and over-logging have exacerbated soil erosion, which is believed to threaten the safety of more than 100 million Chinese living in downstream sections of rivers in the eastern coastal region (Liu and Wu 2010). In particular, the massive floods of 1998, which resulted in more than 4000 deaths and serious economic damages, were blamed on soil erosion due to logging and deforestation in the Yangtze and Yellow River basins (Gutiérrez Rodríguez et al. 2016, Jin et al. 2017).

This perception that deforestation was to blame for the flooding led directly to the National Forest Protection Program, which banned logging, and the SLCP, which initially subsidised farmers to convert cropland to forest or grassland in the basins that had suffered flooding. In 2002, the Chinese government expanded the SLCP to cover most of the country (Liu et al. 2008). Under this programme, farmers with land prone to soil erosion and desertification are encouraged to convert agricultural fields to forest or grassland with subsidies from the government (Liu and Wu 2010). The subsidies, which many authors describe as PES, have been in the form of grain or cash. In their systematic review of the literature on the programme, Gutiérrez Rodríguez et al. (2016) find that most studies confirm the expected positive impact of the programme on forest cover and tree planting. Chen et al. (2015) concur that forest cover has increased, but note that some studies have raised questions about how much of the increase should be attributed to the SLCP and about the effects on ecosystem services.

In summary, forests have been recognised as potentially reducing both exposure and vulnerability to environmental shocks, including the extreme weather events that are expected to increase in frequency and severity with climate change. Particularly for the poorest and most vulnerable communities, investing in ecosystem services may be more effective, efficient and 
sustainable than infrastructure or technological options for adaptation (Locatelli et al. 2008). Thus, Target 1.5 provides an incentive to invest in forest protection and reforestation, especially in coastal zones, on steep slopes, in areas at risk of desertification and in critical watersheds. While these investments may be more likely to happen after a disaster (e.g. SLCP implementation in the wake of catastrophic floods), there are increasing calls to proactively implement ecosystem-based adaptation, including through afforestation and reforestation.

\subsection{Conclusion and Means of Implementation}

As with most SDGs, the suggested means of implementation for SDG 1 are mobilisation of resources and investment. For SDG 1, these are indicated by the proportion of government spending and international aid (grants and non-debt-creating inflows) allocated to three priorities: (1) poverty reduction; (2) education, health and social protection; and (3) sectors that disproportionately benefit women, the poor and vulnerable groups. While international aid to a country is not strictly a zero-sum game, clearly all governments operate under budget constraints. In this context, increasing the proportions of government spending and international aid on the priorities identified for SDG 1 could reduce the proportions of spending and aid allocated to forests (also a prominent concern for biodiversity; see Roe et al. 2013, Sanderson and Redford 2003). This could exacerbate the underfunding of the forest sector (Agrawal et al. 2013). Furthermore, as illustrated by the PRSPs, most governments prioritise infrastructure and agricultural development to alleviate rural poverty, with likely negative impacts on forests.

These trade-offs can be avoided if forests are understood to be fundamental to poverty reduction and hence included either as a means of poverty reduction (e.g. as part of ecosystem-based adaptation) or as a condition of poverty-reduction policies (e.g. social protection or titling policies that require commitments to forest conservation). Given the concentration of poverty in Africa, this is particularly important for the future of forests on that continent. There is some evidence that donors and governments are increasingly recognising the potential synergies between forest conservation and poverty reduction (Leisher et al. 2013). For example, Ethiopia's climateresilient green economy strategy includes forest protection and restoration as one of the four pillars of economic development (FDRE 2011). Bilateral donors have invested resources in understanding forest-poverty relationships - for example, through the Ecosystem Services for Poverty Alleviation programme (Schreckenberg et al. 2018). This programme was funded by the UK's Department for International Development, along with the Economic 
and Social Research Council and Natural Environment Research Council. Likewise, CIFORs ${ }^{4}$ Poverty and Environment Network attracted funding from international donors for rigorous research that carefully quantified the contribution of forest products to local livelihoods (Wunder et al. 2014).

While the importance of ecosystem goods and services to the rural poor has been established by this line of research, there is much less evidence on the types of interventions that can successfully achieve both forest conservation and poverty reduction (cf. Adams et al. 2004). For example, reviews of integrated conservation and development projects have generally concluded that most fail to achieve their goals (Naughton-Treves et al. 2005), and even that those goals are fundamentally contradictory (Miller et al. 2011). Likewise, the literature on PES has been cautious about its potential to simultaneously achieve forest conservation and poverty reduction, in part because these two goals may require different spatial targeting (Alix-Garcia et al. 2013, 2015; James and Sills 2018). Systematic reviews of the literature have found no evidence that PES harms recipients, but little evidence of benefits (Sills and Jones 2018).

Forest conservation is often pursued through reallocation of property rights to forests, either to government agencies to manage as protected areas or to communities to manage under sustainability requirements enforced by the government. Intuition suggests that restricting access to forest in protected areas should have a negative effect on local incomes, while decentralisation of forest management should increase incomes. However, recent research using rigorous quasi-experimental methods has found that protected areas can help alleviate poverty, with tourism as the likely mechanism (den Braber et al. 2018, Ferraro and Hanauer 2014, Pullin et al. 2013, Robalino and Villalobos-Fiatt 2015, Sims 2010). In a systematic review of impact evaluations of decentralisation, Samii et al. (2014) find three studies that report a positive effect on participants' household income (from forests or in total), suggesting a fairly thin evidence base. Further research into how impacts are moderated by institutions and other contextual factors is needed to understand the potential to achieve SDG 1 through forest initiatives (Sills and Jones 2018). Research that differentiates impacts on women, the poor and vulnerable groups may identify windows of opportunity or challenges. For example, Duchelle et al. (2018) report that REDD+ initiatives that limit deforestation have generally not negatively impacted local incomes. In sites where there have been negative impacts, they are concentrated among the highestincome households, resulting in greater equality of income. In the same sample, Larson et al. (2018) find negative impacts of REDD+ on women except

\footnotetext{
${ }^{4}$ Centre for International Forestry Research.
} 
in sites where there were explicit strategies to address their priorities (also see Chapter 5). Thus, opportunities for win-wins may be fairly narrowly defined and require detailed analysis and tailored policies.

In sum, the specific targets for SDG 1 include social protection, secure land tenure and reducing exposure and vulnerability to environmental shocks. The empirical literature shows that cash transfers as well as more secure property rights - especially for community land - can be conducive to forest conservation, given the right context and conditionalities. As demonstrated by programmes to reforest hillsides and protect mangroves, initiatives to reduce vulnerability to environmental shocks can adopt an ecosystem-based adaptation approach, thereby promoting an expansion of forest cover. This approach is consistent with the scientific evidence that forests are both a mainstay of rural livelihoods and a source of natural insurance. However, there is relatively little evidence that this scientific knowledge is shaping poverty reduction and national development strategies. To the extent that those strategies are based on infrastructure and agricultural development, they are likely to remain in conflict with forest conservation and sustainable management.

\section{References}

Adams, W. M., Aveling, R., Brockington, D. et al. 2004. Biodiversity conservation and the eradication of poverty. Science 306(5699):1146-49.

Agrawal, A., Cashore, B., Hardin, R., et al. 2013. Economic contributions of forests. Background Paper 1: Economic contributions of forests. United Nations Forum on Forests. Tenth Session. 8-19 April, Istanbul. Turkey.

Alix-Garcia, J. M., McIntosh, C., Sims, K. R. E. and Welch, J. R. 2013. The ecological footprint of poverty alleviation: Evidence from Mexico's Oportunidades program. Review of Economics and Statistics 95(2):417-35.

Alix-Garcia, J. M., Sims, K. R. and Yañez-Pagans, P. 2015. Only one tree from each seed? Environmental effectiveness and poverty alleviation in Mexico's Payments for Ecosystem Services Program. American Economic Journal: Economic Policy 7(4):1-40.

Alix-Garcia, J. M. and Wolff, H. 2014. Payment for ecosystem services from forests. Annual Review of Resource Economics 6(1):361-80.

Alston, L. J., Libecap, G. D. and Mueller, B. 2000. Land reform policies, the sources of violent conflict, and implications for deforestation in the Brazilian Amazon. Journal of Environmental Economics and Management 39(2):162-88.

Angelsen, A. 2010. Policies for reduced deforestation and their impact on agricultural production. Proceedings of the National Academy of Sciences 107(46):19639-44.

Angelsen, A., Jagger, P., Babigumira, R. et al. 2014. Environmental income and rural livelihoods: A global-comparative analysis. World Development 64:12-28. 
Angelsen, A. and Rudel, T. K. 2013. Designing and implementing effective REDD+ policies: A forest transition approach. Review of Environmental Economics and Policy 7(1):91-113.

Asfaw, S., Pickmans, R., Alfani, F. and Davis, B. 2016a. Productive impact of Ethiopia's Social Cash Transfer Pilot Programme. A From Protection to Production report. Rome: FAO.

Asfaw, S., Pickmans, R. and Davis, B. 2016b. Productive impact of Malawi's Social Cash Transfer Programme - midterm report. From Protection to Production report. Rome: FAO.

Atmadja, S. and Sills E. 2015. Identifying the causes of tropical deforestation: Meta-analysis to test and develop economic theory. In Köhl, M. and Pancel L. (eds.) Tropical forestry handbook. Berlin Heidelberg: Springer Verlag, pp. 1-27.

Baird, S., Ferreira, F. H., Özler, B. and Woolcock, M. 2014. Conditional, unconditional and everything in between: A systematic review of the effects of cash transfer programmes on schooling outcomes. Journal of Development Effectiveness 6(1):1-43.

Barbier, E. B. 2010. Poverty, development, and environment. Environment and Development Economics 15(4):635-60.

Barbier, E. B. and Tesfaw, A. T. 2013. Tenure constraints and carbon forestry in Africa. American Journal of Agricultural Economics 95(4):964-75.

Barrett, C. B. 2005. Rural poverty dynamics: Development policy implications. Agricultural Economics 32(s1):45-60.

Bastagli, F., Hagen-Zanker, J., Harman, L. et al. 2016. Cash transfers: What does the evidence say. A rigorous review of programme impact and the role of design and implementation features. London: ODI.

BenYishay, A., Heuser, S., Runfola, D. and Trichler, R. 2017. Indigenous land rights and deforestation: Evidence from the Brazilian Amazon. Journal of Environmental Economics and Management 86:29-47.

Blackman, A., Corral, L., Lima, E. and Asner, G. 2017. Titling Indigenous communities protects forests in the Peruvian Amazon. Proceedings of the National Academy of Sciences 114(16):412328.

Blackman, A. and Veit, P. 2018. Amazon Indigenous communities cut forest carbon emissions. Ecological Economics 153(C):56-67.

Bryan, B. A., Gao, L., Ye, Y. et al. 2018. China's response to a national land-system sustainability emergency. Nature 559(7713):193.

Buntaine, M., Hamilton, S. and Millones, M. 2015. Titling community land to prevent deforestation: An evaluation of a best-case program in Morona-Santiago, Ecuador. Global Environmental Change 33:32-43.

Busch, J. and Ferretti-Gallon, K. 2017. What drives deforestation and what stops it? A metaanalysis. Review of Environmental Economics and Policy 11(1):3-23.

Byron, N. and Arnold M. 1999. What futures for the people of tropical forests? World Development 27(5):789-805.

Call, M., Mayer, T., Sellers, S. et al. 2017. Socio-environmental drivers of forest change in rural Uganda. Land Use Policy 62:49-58. 
Chazdon, R., Brancalion, P., Laestadius, L. et al. 2016. When is a forest a forest? Forest concepts and definitions in the era of forest and landscape restoration. Ambio 45(5):538-50.

Chen, C., König, H. J., Matzdorf, B. and Zhen, L. 2015. The institutional challenges of payment for ecosystem service program in China: A review of the effectiveness and implementation of Sloping Land Conversion Program. Sustainability 7(5):5564-91.

Cheng, S. H., Ahlroth, S., Onder, S. et al. 2017. What is the evidence for the contribution of forests to poverty alleviation? A systematic map protocol. Environmental Evidence 6(1):10.

Choumert, J., Motel, P. C. and Dakpo, H. K. 2013. Is the Environmental Kuznets Curve for deforestation a threatened theory? A meta-analysis of the literature. Ecological Economics 90:19-28. http://dx.doi.org/10.1016/j.ecolecon.2013.02.016

Daidone, S., Davis, B., Dewbre, J. and Covarrubias, K. 2014. Lesotho's Child Grant Program: 24-month impact report on productive activities and labour allocation. Lesotho country case study report. Protection to Production Project Report. Rome: FAO.

Das, S. and Vincent, J. R. 2009. Mangroves protected villages and reduced death toll during Indian super cyclone. Proceedings of the National Academy of Sciences 106(18):7357-60.

Daw, T., Brown, K., Rosendo, S. and Pomeroy, R. 2011. Applying the ecosystem services concept to poverty alleviation: The need to disaggregate human well-being. Environmental Conservation 38(4):370-79.

Day M., Gumbo, D., Moombe, K. B., Wijaya, A. and Sunderland, T. 2014. Zambia country profile: Monitoring, reporting and verification for REDD+. CIFOR Occasional Paper 113. Bogor, Indonesia: Center for International Research (CIFOR).

Democratic Republic of Congo. 2006. Poverty reduction and growth strategy paper. Available at: http://siteresources.worldbank.org/INTPRS1/Resources/Demrepofcongo_PRSP(Sept2007).pdf (Accessed 22 February 2019).

den Braber, B., Evans, K. L. and Oldekop, J. A. 2018. Impact of protected areas on poverty, extreme poverty, and inequality in Nepal. Conservation Letters 11(6):e12576.

Doswald, N., Munroe, R., Roe, D., et al. 2014. Effectiveness of ecosystem-based approaches for adaptation: Review of the evidence-base. Climate and Development 6(2):185-201.

Dorner, P. and Thiesenhusen, W. 1992. Land tenure and deforestation: Interactions and environmental Implication. Discussion Paper. Geneva: United Nations Research Institute for Social Development (UNRISD).

Duchelle, A. E., de Sassi, C., Sills, E. O. and Wunder, S. 2018. People and communities: Wellbeing impacts of REDD+ on the ground. In Angelsen, A., Martius, C., de Sy, V. et al. (eds.) Transforming REDD+: Lessons and new directions. Bogor, Indonesia: Center for International Forestry Research, pp. 131-43.

Elbow, K. 2014. What is tenure security? Why does it matter? USAID. Available at: www.land-links .org/wp-content/uploads/2017/02/USAID_Land_Tenure_2014_Haiti_Training_Module_1_ Presentation_2_Elbow.pdf (Accessed 23 July 2019).

FDRE 2011. Ethiopia's climate-resilient green economy: Green Economy Strategy. Addis Ababa, Ethiopia: FDRE. 
Ferraro, P. and Simorangkir R. 2018. Environmental consequences of poverty alleviation programs:

Evidence from conditional cash transfers in Indonesia. Conference Paper, 6th World Congress of Environmental and Resource Economists. Gothenburg, Sweden.

Ferraro, P. J. and Hanauer, M. M. 2014. Quantifying causal mechanisms to determine how protected areas affect poverty through changes in ecosystem services and infrastructure. Proceedings of the National Academy of Sciences:1-6.

Ferreira, F. H. G., Chen, S., Dabalen, A. L. et al. 2015. A global count of the extreme poor in 2012: data issues, methodology and initial results. Policy Research Working Paper no. WPS 7432. Washington, DC: World Bank Group. Available at: http://documents.worldbank.org/ curated/en/360021468187787070/A-global-count-of-the-extreme-poor-in-2012-data-issuesmethodology-and-initial-results (Accessed 22 February 2019).

Gertler, P. J., Martinez, S. W. and Rubio-Codina, M. 2012. Investing cash transfers to raise longterm living standards. American Economic Journal: Applied Economics 4(1):164-92.

Gilliand, T. E., Sanchirico, J. N. and Taylor, J. E. 2018. Environmental impacts of cash transfer programs: Implications for the welfare of poor communities in developing countries. Conference Paper, 6th World Congress of Environmental and Resource Economists, Gothenburg, Sweden. Gutiérrez Rodríguez, L., Hogarth, N. J., Zhou, W. et al. 2016. China's conversion of cropland to forest program: A systematic review of the environmental and socioeconomic effects. Environmental Evidence 5:21.

Hallegatte, S., Bangalore, M., Bonzanigo, L. et al. 2016. Shock waves: Managing the impacts of climate change on poverty. Climate Change and Development. Washington, DC: World Bank.

Handa, S., Daidone, S. Peterman, A. et al. 2017. Myth-busting? Confronting six common perceptions about unconditional cash transfers as a poverty reduction strategy in Africa. Innocenti Working Paper 2017-11. Florence: UNICEF Office of Research.

Handa, S., Natali, L., Seidenfeld, D., Tembo, G. and Davi, B. 2018. Can unconditional cash transfers raise long-term living standards? Evidence from Zambia. Journal of Development Economics 133:42-65.

Holland, M., Jones, K., Naughton-Treves, L. et al. 2017. Titling land to conserve forests: The case of Cuyabeno Reserve in Ecuador. Global Environmental Change 44:27-38.

Hulme, D., Hanlon, J. and Barrientos, A. 2012. Just give money to the poor: The development revolution from the Global South. Herndon: Kumarian Press.

IMF 2018. Factsheet: Debt Relief under the Heavily Indebted Poor Countries (HIPC) Initiative. Available at: www.imf.org/en/About/Factsheets/Sheets/2016/08/01/16/11/Debt-Relief-Underthe-Heavily-Indebted-Poor-Countries-Initiative (Accessed 16 February 2019).

James, N. and Sills, E. 2018. Payments for ecosystem services. Oxford encyclopedia of environmental economics. doi:10.1093/acrefore/9780199389414.013.580

Jin, L., Porras, I., López, A. and Kazis, P. 2017. Sloping Lands Conversion Programme, People's Republic of China. Conditional transfers, poverty and ecosystems: National programmes highlights. London: IIED. Available at: https://pubs.iied.org/pdfs/G04188.pdf (Accessed 28 July 2019). 
Land Portal 2018. Land and the Sustainable Development Goals (SDGs). Available at: https:// landportal.org/book/sdgs/14/indicator-142 (Accessed 22 February 2019).

Lao PDR (People's Democratic Republic) 2006. National Socio-Economic Development Plan (2006-2010). Vientiane, Lao: PDR. Available at: http://siteresources.worldbank.org/INTPRS1/ Resources/LAO_PRSP2(Oct2008).pdf (Accessed 9 August 2018).

Larson, A. M., Brockhaus, M., Sunderlin, W. D. et al. 2013. Land tenure and REDD+: The good, the bad and the ugly. Global Environmental Change 23(3):678-89.

Larson, A. M., Solis, D., Duchelle, A. E. et al. 2018. Gender lessons for climate initiatives: A comparative study of REDD+ impacts on subjective wellbeing. World Development 108:86-102.

Lawlor, K. 2015. Poverty-environment relationships under market heterogeneity: Cash transfers and producer-consumers in Zambia. (Chapter 3 in PhD diss.: Impacts of Poverty Reduction in Remote Rural Landscapes: Evidence from Cash Transfers in Zambia. University of North Carolina, Chapel Hill, NC). Available at: https://cdr.lib.unc.edu/indexablecontent/ uuid:801cb5e9-ed43-4231-89e2-be4989eb8ba9 (Accessed 16 February 2019).

Lawlor, K., Madeira, E. M., Blockhus, J. and Ganz, D. J. 2013. Community participation and benefits in REDD+: A review of initial outcomes and lessons. Forests 4:296-318.

Leisher, C., Sanjayan, M., Blockhus, J., Larsen, N. and Kontoleon, A. 2013. Does conserving biodiversity work to reduce poverty? A state of knowledge review. In Roe, D., Elliott, J., Sandbrook, C., Walpole, M. (eds.) Biodiversity conservation and poverty alleviation: Exploring the evidence for a link (1st ed.) Hoboken: John Wiley \& Sons, pp. 43-59.

Lin, Y., Qu, M., Liu, C. and Yao, S. 2018. Land tenure, logging rights, and tree planting: Empirical evidence from smallholders in China. China Economic Review. doi:10.1016/j. chieco.2018.08.011.

Liscow, Zachary D. 2013. Do Property Rights Promote Investment but Cause Deforestation? Quasi-Experimental Evidence from Nicaragua. Journal of Environmental Economics and Management 65(2). Available at: https://ssrn.com/abstract=2297090 (Accessed 28 July 2019).

Liu, C. and Wu, B. 2010. Grain for Green Programme in China: Policy making and implementation. Nottingham: University of Nottingham China Policy Institute. Available at: www .nottingham.ac.uk/iaps/documents/cpi/briefings/briefing-60-reforestation.pdf (Accessed 16 February 2019).

Liu, J. and Diamond, J. 2005. China's environment in a globalizing world. Nature 435:1179-86.

Liu, J., Li, S., Ouyang, Z., Tam, C. and Chen, X. 2008. Ecological and socioeconomic effects of China's policies for ecosystem services. Proceedings of the National Academy of Sciences 105(28):9477-82.

Locatelli, B., Kanninen, M., Brockhaus, M. et al. 2008. Facing an uncertain future: How forests and people can adapt to climate change. Forest Perspectives No. 5. Bogor, Indonesia: CIFOR.

López-Feldman, A. and Chávez, E. 2017. Remittances and natural resource extraction: Evidence from Mexico. Ecological Economics 132:69-79.

L'Roe, J., Rausch, L., Munger, J. and Gibbs, H. 2016. Mapping properties to monitor forests: Landholder response to a large environmental registration program in the Brazilian Amazon. Land Use Policy 57:193-203. 
Maini, J. S. 2003. International dialogue on forests: Impact on national policies and practices. In Teeter, L., Cashore, B. and Zhang, D. (eds.) Forest Policy for Private Forestry - Global and Regional Challenges, Wallingford: CABI Publishing, pp. 9-15.

Manley, J., Gitter, S. and Slavchevska, V. 2013. How effective are cash transfers at improving nutritional status? World Development 48:133-55.

Miller, T. R., Minteer, B. A. and Malan, L. C. 2011. The new conservation debate: The view from practical ethics. Biological Conservation 144:948-57.

Mongolia 2003. Economic growth support and poverty reduction strategy. Ulaanbaatar, Mongolia: Government of Mongolia. Available at: http://siteresources.worldbank.org/INTPRS1/ Resources/Country-Papers-and-JSAs/Mongolia_PRSP.pdf (Accessed 22 February 2019).

Munang, R., Thiaw, I., Alverson, K. et al. 2013. Climate change and ecosystem-based adaptation: A new pragmatic approach to buffering climate change impacts. Current Opinion in Environmental Sustainability 5(1):67-71.

Naughton-Treves, L., Holland, M. B. and, Brandon, K. 2005. The role of protected areas in conserving biodiversity and sustaining local livelihoods. Annual Review of Environment and Resources 30:219-52

Pattanayak, S. K. and Sills, E. O. 2001. Do tropical forests provide natural insurance? The microeconomics of non-timber forest product collection in the Brazilian Amazon. Land Economics 77(4):595-612.

Pfaff, A., Robalino, J., Walker, R. et al. 2007. Road investments, spatial spillovers and deforestation in the Brazilian Amazon. Journal of Regional Science 47:109-23.

Pullin, A., Bangpan, M., Dalrymple, S. et al. 2013. Human well-being impacts of terrestrial protected areas. Environmental Evidence 2(19).

Puppim de Oliveira, J. 2008. Property rights, land conflicts and deforestation in the eastern Amazon. Forest Policy and Economics 10(5):303-15.

Pramova, E., Locatelli, B., Djoudi, H. and Somorin, O. A. 2012. Forests and trees for social adaptation to climate variability and change. WIREs Climate Change 3:581-96.

Republic of Bolivia 2001. Poverty Reduction Strategy Paper - PRSP. La Paz: Republic of Bolivia. Available at: http://siteresources.worldbank.org/INTPRS1/Resources/Country-Papers-andJSAs/bolivaprsp.pdf (Accessed 9 August 2018).

Republic of Congo 2012. Congo National Development Plan, Book 1: Growth, employment, and poverty reduction strategy paper (2012-2016 DSCERP). Ministry of Economy, Planning, Land Reform and Integration, Republic of Congo. Available at: http://siteresources.worldbank.org/ INTPRS1/Resources/Congo-PRSP(August2012).pdf (Accessed 9 August 2018).

Republic of Guinea-Bissau 2011. Second National Poverty Reduction Strategy Paper. Ministry of Economy, Planning and Regional Integration, Bissau, Guinea-Bissau. Available at: http:// siteresources.worldbank.org/INTPRS1/Resources/Gineau-Bisseau_PRSP(Dec2011).pdf (Accessed 9 August 2018).

Republic of Zambia 2006. Fifth National Development Plan 2006-2010. Republic of Zambia. http://siteresources.worldbank.org/INTPRS1/Resources/Zambia_PRSP(Dec2006).pdf (Accessed 9 August 2018). 
Robalino, J. and Villalobos-Fiatt, L. 2015. Protected areas and economic welfare: An impact evaluation of national parks on local workers' wages in Costa Rica. Environment and Development Economics 20(3):283-310.

Robinson, B. E., Holland, M. B. and Naughton-Treves, L. 2014. Does secure land tenure save forests? A meta-analysis of the relationship between land tenure and tropical deforestation. Global Environmental Change 29:281-93.

Robinson, B. E., Holland, M. B. and Naughton-Treves, L. 2017. Community land titles alone will not protect forests. Proceedings of the National Academy of Sciences 114(29):E5764.

Rodríguez, L. C., Pascual, U., Muradian, R., Pazmino, N. and Whitten, S. 2011. Towards a unified scheme for environmental and social protection: Learning from PES and CCT experiences in developing countries. Ecological Economics 70(11):2163-74.

Roe, D. 2013. Has biodiversity fallen off the development agenda? A case study of the UK Department for International Development. Oryx 47(1):113-21.

Roe, D., Mohammed, E. Y., Porras, I. and Giuliani, A. 2013. Linking biodiversity conservation and poverty reduction: De-polarizing the conservation-poverty debate. Conservation Letters 6(3):162-71.

Royal Government of Bhutan 2004. Poverty Reduction Strategy Paper: A cover note to the ninth plan main document. Ministry of Finance, Royal Government of Bhutan. Available at: http:// siteresources.worldbank.org/INTPRS1/Resources/Country-Papers-and-JSAs/cr04246.pdf (Accessed 9 August 2018).

Rudel, T. K., Coomes, O. T., Moran, E. et al. 2005. Forest transitions: Towards a global understanding of land use change. Global Environmental Change 15(1):23-31.

Samii, C., Lisiecki, M., Kulkarni, P., Paler, L. and Chavis, L. 2014. Effects of payment for environmental services (PES) on deforestation and poverty in low and middle income countries: A systematic review. Campbell Systematic Reviews 10(11):1-95.

Sanderson, S. E. and Redford, K. H. 2003. Contested relationships between biodiversity conservation and poverty alleviation. Oryx 37(4):389-90.

Schreckenberg, K., Poudyal, M. and Mace, G. 2018. Ecosystem services and poverty alleviation: Trade-offs and governance. Routledge. Available at: www.routledge.com/Ecosystem-Servicesand-Poverty-Alleviation-OPEN-ACCESS-Trade-offs-and/Schreckenberg-Mace-Poudyal/p/ book/9781138580848 (Accessed 29 July 2019)

Sen, A. 1999. Development as freedom. New York: Anchor Books.

Shackleton, S., Delang, C. O. and Angelsen, A. 2011. From subsistence to safety nets and cash income: Exploring the diverse values of non-timber forest products for livelihoods and poverty alleviation. In Shackleton, S., Shackleton, C. and Shanley, P. (eds.) Non-timber forest products in the global context. Berlin: Springer, pp. 55-81.

Sierra, R. and Russman, E. 2006. On the efficiency of environmental service payments: A forest conservation assessment in the Osa Peninsula, Costa Rica. Ecological Economics 59(1):131-41.

Sills, E. and Jones, K. 2018. Causal inference in environmental conservation: The role of institutions. In Dasgupta, P., Pattanayak, S. K. and Smith, V. K. (eds.) Handbook of environmental economics, vol. 4. Amsterdam: Elsevier, pp. 395-437. 
Sims, K. R. E. 2010. Conservation and development: Evidence from Thai protected areas. Journal of Environmental Economics and Management 60(2):94-114.

Sjaastad, E. D. and Bromley, D. W. 2000. The prejudices of property rights: On individualism, specificity and security in property regimes. Development Policy Review 18:365-389.

Sunderlin, W. D., Dewi, S., Puntodewo, A. et al. 2008. Why forests are important for global poverty alleviation: A spatial explanation. Ecology and Society 13(2). Available at: www .ecologyandsociety.org/vol13/iss2/art24/ (Accessed 28 July 2019).

Tirivayi, N., Knowles. M. and Davis, B. 2016. The interaction between social protection and agriculture: A review of evidence. Global Food Security 10:52-62.

Tirivayi, N., Rodriguez, O., Juvenal, T. and Ma, Q. 2017. Social protection for forest-dependent communities. FAO Policy Brief. Rome: FAO. Available at: www.fao.org/3/a-i7008e.pdf (Accessed 15 February 2019).

Todd, J., Winters, P. and Hertz, T. 2010. Conditional cash transfers and agricultural production: Lessons from the Oportunidades experience in Mexico. Journal of Development Studies 46(1):39-67.

UNDP 2018. Multidimensional poverty index. http://hdr.undp.org/en/2018-MPI (Accessed 16 February 2019).

United Republic of Tanzania 2010. National Strategy for Growth and Reduction of Poverty II. Dar es Salaam, Tanzania: Ministry of Finance and Economic Affairs, United Republic of Tanzania. Available at: http://siteresources.worldbank.org/INTPRS1/Resources/Tanzania-PRSP-Dec2010 .pdf (Accessed 9 August 2018).

Vignola, R., Locatelli, B., Martinez, C. and Imbach, P. 2009. Ecosystem-based adaptation to climate change: What role for policy-makers, society and scientists? Mitigation and Adaptation Strategies for Global Change 14:691-96.

Watmough, G. R., Atkinson, P. M., Saikia, A., and Hutton, C. W. 2016. Understanding the evidence base for poverty-environment relationships using remotely sensed satellite data: An example from Assam, India. World Development 78:188-203.

White, A. and Martin, A. 2002. Who owns the world's forests? Forest tenure and public forests in transition. Washington, DC: Forest Trend \& Center for International Environmental Law.

World Bank 2018. Poverty and Shared Prosperity 2018: Piecing Together the Poverty Puzzle. Washington, DC: World Bank. License: Creative Commons Attribution CC BY 3.0 IGO

World Bank 2001. World development report 2000/2001: Attacking poverty. New York: Oxford University Press New York.

Wunder, S., Angelsen, A. and Belcher, B. 2014. Forests, livelihoods, and conservation: Broadening the empirical base. World Development 64:S1-11.

Yin, R., Zulu, L., Qi, J., Freudenberger, M. and Sommerville, M. 2016. Empirical linkages between devolved tenure systems and forest conditions: Challenges, findings, and recommendations. Forest Policy and Economics 73:294-9. 